JOAL, (JOURNAL, OF APPIIII) LINGUIS'IICS ANI) III'BRA'TURE)

Vol. 4 No. 1, 2019

ISSN (print): 2502-7816; ISSN (online): 2503-524X

Available online at https:/ / ejournal.unib.ac.id/index.php/joall/index

doi: $10.33369 /$ joall.v4i1.7387

\title{
NORTHERN IRISH ADOLESCENTS' ATTITUDES TOWARDS LEARNING A FOREIGN LANGUAGE: WHAT CAN WE LEARN FROM THEM?
}

\author{
1Udi Samanhudi \\ ${ }^{1}$ Universitas Sultan Ageng Tirtayasa, Banten \\ Corresponding author: udisamanhudi@untirta.ac.id
}

\begin{abstract}
Over the last few decades, scholars concerned with language and education have studied the relationship between adolescents' attitudes and foreign language learning. This topic has been an important area of study in the field of applied linguistics predominantly from a psychological perspective. This research used secondary data from the Young Life and Times (YLT) and employed a descriptive qualitative research with a cross-sectional design. The Chi-Square test was used in order to test the five hypotheses proposed in this study. This present study found that gender and residential locations were significant factors relating to the 16-year old adolescents' attitudes toward learning a foreign language. Conversely, this study found that there was no statistically significant evidence of differences among the other three variables (the family affluence, school types attended and religions) in relation to the young people's attitudes to the foreign language. This finding may be useful as a reflection of how the current modern language learning policy is implemented and how teenagers especially in the context of Northern Ireland respond to the policy.
\end{abstract}

Keywords: Adolescents' Attitudes, Learning, foreign language learning

\section{INTRODUCTION}

Over the last few decades, scholars concerned with language and education have studied the relationship between adolescents' attitudes and foreign language learning. This topic has been an important area of study in the field of applied linguistics predominantly from a psychological perspective (e.g., Ellis, 2015; Kobayashi, 2002; McGroarty, 1996; Dornyei, 1994). In the context of Northern Ireland as a heterogeneous community (Hughes, et al., 2011), external factors may influence people's attitudes especially adolescents to foreign languages. These external factors may include specific 'social variables' (Lopez, 2006., p. 99), for example, gender, residential location, school type attended, family affluence and religion which have so far been considered as important variables potentially influencing 
Northern Irish adolescents' attitudes towards learning a foreign language...

adolescents' attitudes toward foreign language learning (e.g., Titus et al., 2016; Mburu, 2013; Studenska, 2011; Lopez, 2006; Kobayashi, 2002).

This study, then, aims to further investigate the 16-year old adolescents' attitudes to foreign language learning based on five different characteristics; gender, residential location, school type attended, family affluence and religion in Northern Ireland. Thus, the first part of this paper pinpoints some related theories drawing from previous studies on the attitudes towards foreign language learning. These studies are broadly concerned with attitudes to foreign language learning based on five different characteristics (gender, residential location, school type attended, family affluence and religion). Additionally, current UK policy towards modern language learning will be discussed. The second part of this paper discusses the methodology of the research. Following this, the third section discusses results and discussions of the findings of this study. This is followed by a range of conclusions and limitations drawn from the study.

Attitude, defined as 'people inclination to respond favourably or unfavourably with respect to an object' (Lopez, 2006, p. 3), is an important element in a foreign language learning as documented in much literature (Masgoret \& Gardner, 2003; Starks \& Paltridge, 1996; Boninger et al., 1995). For example, Boninger et al., (1995) said that attitudes play an important role for people to process any information, to make decisions and to take actions in their life (Howe \& Krosnick, 2016) including learning a foreign language (Cohen, 2004). This suggests, in the context of adolescents as school students, that improving their attitudes in learning a foreign language is potentially able to boost their interest and motivation to study and to master the language well (Cohen, 2014; Hedge, 2011; Tierney \& Gallastegi, 2011; Bybee \& McCrae, 2011; Masgoret \& Gardner, 2003; Gardner, 1985). For instance, Gardner (1985) argued that an attitude toward learning a foreign language is an important component of motivation that can help one to succeed in the process of language learning and acquisition (Karahan, 2007). Specifically, Wenden (1991) divided attitudes into three essential components including cognitive, evaluative and behavioural parts. The first one refers to one's perceptions about objects which are related to the attitude. The second, evaluative component refers to a sense of like and dislike creations in relation to situations related to the attitude. The last component deals with learners' attempts to adopt a certain learning behavioural (Karahan, 2007; Starks \& Paltridge, 1996). The interplay among these three components, Wenden (1991) further argued, helps one to decide to respond favourably or unfavourably toward something including, for example, a foreign language learning (Lopez, 2006). 
In the context UK in general and the Northern Ireland in particular, developing positive attitudes to learning a foreign language among young people is becoming vital in order to support the Languages for All: Languages for Life policy aims to prepare the young people in the UK to be more competitive in the globalized market in the future (DfES, 2002). Thus, encouraging adolescents' positive attitudes toward learning a foreign language, Tierney \& Gallastegi (2011) argued, can be done by showing them advantages they may gain from learning that language. For example, it is possible that they can develop their linguistic competence and cultural diversity awareness through a foreign language they learn which at the same time may also build confidence and transferable skills important in their life (Studenska, 2011; Chiswick \& Miller, 2003). In addition, it is likely that those who are mastering foreign language skills would typically gain wider possibilities for a better job and earnings in their future life (Aldashev et al., 2009; Berman, Lang, \& Siniver, 2003; Chiswick \& Miller, 2003).

However, instilling good attitudes is a complicated process as it may be affected by various internal or external factors (Mburu, 2013). Current studies on one's attitudes toward learning a foreign language, for example, have reported relations of various external factors including gender, residential location, types of school, religion and family affluence (e.g., Mburu, 2013; Rua, 2006; Kobayashi, 2002; Clark \& Trafford, 1995; Ellis, 1994). Some of those studies reported the significant relationship statistically of those factors (Titus et al, 2016; Kobayashi, 2002; Clark \&Trafford, 1995; Ellis, 1994) in promoting positive attitudes toward learning a foreign language. However, some other studies reported the opposite findings in that no significant relations are found between each of these variables (gender, residential location, types of school, religion and family affluence) in relation to the attitudes of learning a foreign language (e.g., Igbojinwaekwu, 2015; Bacon, 1992; Boyle, 1987) which indicate that different contexts may generate different cases (Lopez, 2006). Section 2.2 below further discusses various factors and their relations to people's attitudes toward learning a foreign language.

Studies reported the importance of gender as an essential factor that affects one's success in a foreign language learning (e.g., Clark \&Trafford, 1995; Bacon \& Finnemann, 1992; Powell \& Batters, 1985). For example, Powell and Batters (1985) conducted a survey to a large number of students (459 boys and 494 girls) in six mixed comprehensive schools in the United Kingdom (UK). This study reported that female students tended to show more appreciative attitudes toward learning a foreign language compared to male students who showed the opposite attitudes. Another study conducted by Kobayashi (2002) also reported similar findings in that girls tended to gain a better achievement in language learning due to their positive attitudes 
Northern Irish adolescents' attitudes towards learning a foreign language...

to it (Główka, 2014). Other studies, however, provided evidence that indicates no significant differences between males and females in terms of attitudes toward learning a foreign language (Bacon, 1992; Boyle, 1987). An experiment conducted by Bacon (1992) involving almost one thousand (1000) university-level students learning Spanish indicated no statistically significant differences between male and female in relation to their attitudes in both listening and speaking skills of that language. In addition, Boyle's (1987) study involving four hundred and ninety (490) Chinese college students revealed an interesting finding in that male students outperformed female students in listening skills tests which is in contrast to common findings of studies concerned a similar topic which reported that females are better in foreign language learning (e.g., Główka, 2014; Studenska, 2011; Murphy, 2010). This, Boyle further reported, is due to positive attitudes of these male students toward listening skills of Spanish they learned. All these conflicting research findings are in line with Lopez's statement that either males or females' success in a foreign language learning much depends on other factors like roles of parents and their surrounding environment in general (Lopez, 2006).

In addition to gender, it is also reported that residential location relates to one's attitudes toward learning a foreign language (Oey_Gardiner, 2000). It has been reported that those living in urban areas have more positive attitudes toward learning a foreign language due to a high competition among community members in the urban areas (Opoku-Asare \& Siaw, 2016) and a good support in terms of facilities for their learning (Alordiah, Akpadaka, \& Oviogbodu, 2015; Oey-Gardiner, 2000). However, a study in Nigeria by Igbojinwaekwu (2015) indicated that residential locations have no relations to students' academic achievement in general and in Math in particular as focused in his study (Igbojinwaekwu, 2015).

In addition to residential locations, studies have also reported the relationship between gender and types of schools attended on students' achievement in language learning. For example, Dale (1974) conducted a large-scale study concerned single-sex education in the UK and found that girls in single-sex schools achieved a better achievement level in their overall learning including in the learning of a foreign language due to their positive attitudes to it. More recent studies by Eisenkopf et al., (2012), for example, suggested that both girls and boys studying in unisex schools environment perform better at school because they are more competitive and comfortable compared to those studying in mixed schools (Saidin \& Brahim, 2011; Riordan, 2010; Sullivan et al., 2010). In addition, Sullivan et al., (2010), conducted a study by involving 1958 cohort data and reported that girls who studied in a single-sex school had better chances of passing in the State Olevel exam compared to those girls who studied in the mixed school. 
However, it is reported by other researchers that no relation or effect found between types of school attended and achievements toward a foreign language learning. A study conducted by Daly (1996) in the context of Northern Ireland reported that no significant difference of achievement in terms of learning a foreign language between girls and boys studying either in single-sex or mixed grammar schools. Similar results are also reported that no significant differences found in other subjects including Math and English of boys or girls studying either in single-sex or mixed grammar schools (Daly \& Shuttleworth, 1997).

Moreover, religion is also reported to have a significant relation with one's attitude towards learning a foreign language (Hurtado \& Gurin, 1987) although the role of religion on one's life decision has been debated recently due to the fact that societies today are more secular (Hayes, et al, 2013). Involving 1027 students from four different ethnics and religious groups: Japanese students $(\mathrm{N}=141 / 14 \%)$, Sinhalese students $(\mathrm{N}=303 / 30 \%)$, Tamil students $(\mathrm{N}=283 / 28 \%)$, and Muslim students $(\mathrm{N}=300 / 29 \%)$, Liyanage, et al., (2003) conducted a study focusing on examining the relation of religion and ethnicity on students' attitudes toward a foreign language. The results indicated that ethnicity and religion in combination significantly associate with the attitudes toward learning a foreign language including learning strategy types (metacognitive, cognitive and social affective) used by the students. They, as Liyanage et al., (2003) further reported, applied strategies of learning a foreign language as they learn their holy book for the first time e.g., memorising important words.

Finally, in terms of family affluence, it is reported that parents' socialeconomy status significantly associates with one's attitudes toward learning a new foreign language (e.g., Kormos \& Kiddle, 2010; Rua, 2006). Kormos and Kiddle (2010) conducted a survey to seven hundred and forty (740) secondary school students from different social economy backgrounds in Santiago, the capital of Chile. In this study they found that students' family affluence level background had a close relation to the students' motivation to learn a foreign language. However, as Anderson et al., (2007) reported, the positive relation is not always found between family affluence and attitudes toward learning a foreign language in general as found in other countries such as Brazil and Korea in which students coming from both weak and high economical family background tend to show similar attitudes toward learning a foreign language like English (Anderson et al., 2007, pp. 596-7).

As the studies above indicate the relations of factors such as gender, residential locations, family affluence, types of schools attended and religion on young people's attitudes in general, it is important to understand further impacts of those factors on young people's attitudes in Northern Ireland 
functions, in a small scale, to inform the current policy relating with foreign language as outlined in the National Language Strategy: 'If a child's talent and natural interest in languages is to flourish, early language learning opportunities need to be provided, and their aptitude needs to be tapped into at the earliest opportunity when they are most receptive' (DfES, 2002) as will further discussed in Section 2.2 below.

Scholars have reported the importance of introducing foreign languages since early level of education and this attempt of introducing foreign language education in early levels have been a phenomenon occurring worldwide (Copland \& Garton, 2014). In response to this, the UK government promulgates a policy concerned foreign languages education that is realized in the National Languages Strategy popularly known as Languages for All: Languages for Life. This policy related to foreign language learning emphasises the importance of mastering foreign languages as skills to prepare the young men for a broader cross-cultural understanding and for a wider competition internationally (DfES, 2002). The idea of issuing this national strategy, Cable et al., (2012) said, is encouraged by the fact that British citizens today are less competitive in a globalized economy due to their lack of competence in foreign languages. Hence, the National Languages Strategy particularly aims to encourage especially young men to learn foreign languages (DfES, 2002) given the fact that, as the current survey reported, this nation (UK) is in danger of being left behind due to young people's reluctance to actively participate in the global contacts (British Council \& Think Global, 2011) and lack of awareness of the importance of mastering foreign languages (Diamantatou \& Hawes, 2016; British Council, 2015).

In response to the above explanation that attitudes have been considered as one of the contributing factors in supporting the Languages for All: Languages for Life policy (Diamantatou \& Hawes, 2016; Hunt, 2005), this research attempts to investigate the 16 year old teenagers' attitudes to foreign language learning with a number of research hypotheses below:

a. There are statistically significant differences between young people's attitudes to foreign language learning in relation to their gender.

b. There are statistically significant differences between young people's attitudes to foreign language learning in relation to their residential locations.

c. There are statistically significant differences between young people's attitudes to foreign language learning in relation to schools they attended.

d. There are statistically significant differences between young people's attitudes to foreign language learning in relation to their family affluence. 
e. There are statistically significant differences between young people's attitudes to foreign language learning in relation to their religion.

\section{METHODS}

\section{Research Design}

This research used secondary data from the Young Life and Times (YLT) survey which has a cross-sectional design. Therefore, this research employs a descriptive qualitative research with a cross-sectional design as suggested by Bryman, (2012). In the context of this study, this research design is used especially to examine the relations of five variables including gender, residential locations, school type attended, religion and family affluence on the 16-year old adolescents' attitudes to foreign language learning.

\section{Data Procedures and Participants}

The data used in this study were taken from a secondary dataset survey. This survey was conducted to measure the attitudes of young people (16 years old adolescents) in Northern Ireland relating to various social issues such as physical activities (sports), experiences at school, sexual exploitation of young people under the age of 18 , careers, community relations, and the adolescents' attitudes to foreign language learning (ARK, 2016). The data set in this free access website are from surveys conducted annually from large and randomly selected samples comprising 103 items covering those issues mentioned above completed by the respondents either online $(15.5 \%)$ or paper based (84.5\%).

In the 2015 Young Life and Times (YLT) survey there were 1158 participants involved. Those participants involved 16-year olds in the Northern Ireland. These participants were young males (42\%) and young females (58\%). The sample selected represented various backgrounds in terms of residential background, family affluence, types of school attended and religions. $59.4 \%$ of the participating respondents were from urban areas and $40.6 \%$ were from rural areas. In terms of family affluence background, $14.8 \%$ were from weak economic background, $53.7 \%$ from average economical background, and $31.5 \%$ is from high economical background family. Moreover, in terms of school the respondents attended, 9.3\% were from Planned Integrated schools, $54.2 \%$ were from Grammar school, 34.3\% were from Secondary school and $2.1 \%$ were from other types of schools in Northern Ireland. Finally, in terms of religion, the percentage of respondents with religion was $70.3 \%$ and those with no religion backgrounds were $29.7 \%$. Hence, the participants involved in this survey were deemed to represent the Northern Ireland adolescents as a whole. 
Northern Irish adolescents' attitudes towards learning a foreign language...

\section{Ethical Issue}

Punch (2015) argued that ethical issues are very important to be taken into consideration by researchers either in primary research or secondary research in which secondary data set publicly available is used. This study, then, used the secondary dataset taken from the 2015 Young Life and Times (YLT) survey (ARK, 2015). It is clearly reported that this publicly accessible survey has fulfilled required ethical guidelines especially to do with the harm, privacy, and confidentiality issues (Cresswell, 2012; Darlington \& Scott, 2002) so that there are no ethical issues associated with its use as secondary data.

\section{Data Analysis}

This study is focused on measuring the associations among five categorical variables: gender, residential location, school type attended, family affluence and religion relating to the adolescents' attitudes toward learning a foreign language. To meet this purpose, this research employed the Chi Square test in order to test the five hypotheses as proposed above. The analysis using the Chi Square test was conducted in this research, firstly, to examine the association between the gender differences and the adolescents' attitudes to the foreign language learning. When the results of analysis indicated statistical relations between gender and the adolescents' attitudes toward learning a foreign language, the Phi value was used to measure the degree of this association (Muijs, 2004). A contingency table and a cluster bar chart were used in this study to show the adolescents' attitudes based on the gender variable.

Secondly, the analysis using the Chi Square test was also conducted in this study to examine the association between residential locations and the adolescents' attitudes to the foreign language learning. When it was found that there was a statistical relation between the two variables, the Phi value was used to measure the degree of this association. Similar to the first two variables analysed (gender differences and the adolescents' attitudes toward learning a foreign language), the contingency table and the cluster bar chart were also used in this second analysis to depict the adolescents' attitudes toward a foreign language learning based on their residential locations. The same analysis was carried out for the rest of the hypotheses in this study focusing on measuring the relationship between the types of school attended, family affluence and religion in relation to the adolescents' attitudes toward a foreign language learning.

\section{FINDINGS}

Variables with Statistically Significant Relations to the 16-Year Old Adolescents' Attitudes toward Foreign Language Learning 
The first hypothesis of this study concerned the relationship between the 16year old adolescents' attitudes to learning a foreign language and their gender. To test this hypothesis, Chi-square test was used. Table 1 shows that there is a statistically significant relationship between gender and attitudes toward learning a foreign language among the 16-year old adolescents in Northern Ireland $\left(X^{2}=27.060, \mathrm{df}=1, \mathrm{p}<0.05\right)$. Although the relationship between gender differences and the adolescents' attitudes to learning a foreign language is weak (Phi 0.154), there is a sufficient evidence to accept the alternative hypothesis as proposed in this study regarding the two variables (Connolly, 2007). This means that there is a statistically significant difference between the 16-year old male and female adolescents in terms of their attitudes toward learning a foreign language.

Table 1. The Proportion of Gender and Attitudes toward Foreign Language Learning

\begin{tabular}{|c|c|c|c|c|c|c|c|c|c|c|}
\hline & \multicolumn{2}{|c|}{ Male } & \multicolumn{2}{|c|}{ Female } & \multicolumn{2}{|c|}{ Total } & \multirow{2}{*}{$X^{2}$} & \multirow{2}{*}{$\mathrm{df}$} & \multirow{2}{*}{$\mathrm{P}$} & \multirow{2}{*}{$\begin{array}{c}\mathrm{Ph} \\
\mathrm{i}\end{array}$} \\
\hline & $\mathrm{n}$ & $\%$ & $\mathrm{~N}$ & $\%$ & $\mathrm{~N}$ & $\%$ & & & & \\
\hline Yes & 371 & 38.4 & 596 & 61.6 & 967 & 100 & $\begin{array}{c}27.0 \\
60\end{array}$ & 1 & $\begin{array}{c}.000 \\
*\end{array}$ & $\begin{array}{c}.15 \\
4\end{array}$ \\
\hline No & 104 & 59.4 & 71 & 40.6 & 175 & 100 & & & & \\
\hline Total & 475 & 41.6 & 667 & 58.4 & $\begin{array}{c}114 \\
2\end{array}$ & 100 & & & & \\
\hline
\end{tabular}

*Statistically significant at $\mathrm{p}<.05$

In addition to gender, Table 2 also demonstrates that there is a statistically significant relationship between residential locations and attitudes toward learning a foreign language among the 16-year old adolescents involved in the survey $\left(X^{2}=9.075, \mathrm{df}=2, \mathrm{p}<0.05\right)$. This indicates that the null-hypothesis as proposed in this study is rejected while the alternative hypothesis is accepted. In other words, it can be said that there are statistically differences between the 16-year old adolescents' attitudes to the foreign language learning and their residential locations. Although the strength of the relationship is relatively weak with the Phi value at 0.090 (Field, 2013), it is also shown in the table that the 16-year old adolescents living in urban areas have better attitudes to learning a foreign language $(61.4 \%)$ as compared to adolescents living in rural areas (36.6\%).

Table 2. Proportion of Residential Locations and Attitudes toward Foreign Language Learning

\begin{tabular}{|c|c|c|c|c|c|c|c|c|c|c|}
\hline & \multicolumn{2}{|c|}{ Urban } & \multicolumn{2}{|c|}{ Rural } & \multicolumn{2}{|c|}{ Total } & \multirow{2}{*}{$X^{2}$} & \multirow{2}{*}{$\mathrm{df}$} & \multirow{2}{*}{$\mathrm{P}$} & \multirow{2}{*}{$\begin{array}{c}\mathrm{Ph} \\
\mathrm{i}\end{array}$} \\
\hline & $\mathrm{N}$ & $\%$ & $\mathrm{~N}$ & $\%$ & $\mathrm{~N}$ & $\%$ & & & & \\
\hline Yes & 590 & 61.4 & 371 & 36.6 & 961 & 100 & $\begin{array}{c}9.07 \\
5\end{array}$ & 1 & $.003^{*}$ & $\begin{array}{c}.09 \\
0\end{array}$ \\
\hline No & 84 & 49.1 & 87 & 50.9 & 171 & 100 & & & & \\
\hline Total & 674 & 59.5 & 458 & 40.5 & $\begin{array}{c}113 \\
2 \\
\end{array}$ & 100 & & & & \\
\hline
\end{tabular}

*Statistically significant at $\mathrm{p}<.05$ 
Northern Irish adolescents' attitudes towards learning a foreign language...

Variables with No Statistically Significant Relations to the 16-Year Old Adolescents' Attitudes toward Foreign Language Learning

While there found significant relations between gender and residential locations toward attitudes of learning of foreign language among the 16-year old teenagers in Northern Ireland, Table 3 indicates that there is no statistical relation between family affluence of the adolescents in Northern Ireland and their attitudes toward learning a foreign language $\left(\mathrm{X}^{2}=1.803, \mathrm{df}=2, \mathrm{p}>\right.$ $0.05)$. This indicates that the null-hypothesis proposed is accepted and thus the alternative hypothesis is rejected. In other words, it can be said that there are no significant differences between young the 16-year old people's attitudes to the foreign language learning in relation to their family affluence. Additionally, table 3 indicates that the proportion of the adolescents from the average economic background who have no attitudes toward learning a foreign language is even higher $(57.7 \%)$ than those from other economic backgrounds (53.7\%).

Table 3. Proportion of Economic Backgrounds and Attitudes toward Foreign

Language Learning

\begin{tabular}{|c|c|c|c|c|c|c|c|c|c|c|c|}
\hline & \multicolumn{2}{|c|}{$\begin{array}{c}\text { Low } \\
\text { Economic } \\
\text { Backgroun } \\
\text { d }\end{array}$} & \multicolumn{2}{|c|}{$\begin{array}{c}\text { Average } \\
\text { Economic } \\
\text { Backgroun } \\
\text { d }\end{array}$} & \multicolumn{2}{|c|}{$\begin{array}{c}\text { High } \\
\text { Economic } \\
\text { Backgroun } \\
\mathrm{d}\end{array}$} & \multicolumn{2}{|c|}{$\underline{\text { Total }}$} & \multirow[t]{2}{*}{$X^{2}$} & \multirow[t]{2}{*}{$\begin{array}{c}D \\
f\end{array}$} & \multirow[t]{2}{*}{$\mathrm{P}$} \\
\hline & $\mathrm{n}$ & $\%$ & $\mathrm{~N}$ & $\%$ & $\mathrm{n}$ & $\%$ & $\mathrm{~N}$ & $\%$ & & & \\
\hline Yes & 135 & 14.8 & 485 & 53.0 & 295 & 32.2 & 915 & $\begin{array}{c}10 \\
0\end{array}$ & $\begin{array}{c}1.80 \\
3\end{array}$ & 2 & $\begin{array}{c}.406 \\
*\end{array}$ \\
\hline No & 25 & 15.3 & 94 & 57.7 & 44 & 27.0 & 163 & $\begin{array}{c}10 \\
0\end{array}$ & & & \\
\hline $\begin{array}{c}\text { Tota } \\
1\end{array}$ & 160 & 14.8 & 579 & 53.7 & 339 & 31.4 & $\begin{array}{c}107 \\
8\end{array}$ & $\begin{array}{c}10 \\
0\end{array}$ & & & \\
\hline
\end{tabular}

*Statistically not significant at $\mathrm{p}>.05$

In addition to family affluence, as demonstrated in Table 4, there found no statistically significant differences between types of school attended by the 16-year old adolescents in relation to their attitudes of learning a foreign language $\left(\mathrm{X}^{2}=4.828, \mathrm{df}=3, \mathrm{p}>0.05\right)$. Given these results, the null-hypothesis is accepted and the alternative hypothesis is rejected. This means that there are no significant differences between adolescents' attitudes to the foreign language learning in relation to the school types they attended.

Table 4. Proportion of Types of Schools Attended and Attitudes toward Foreign Language Learning

\begin{tabular}{|c|c|c|c|c|c|c|c|c|c|c|c|c|}
\hline & \multicolumn{2}{|c|}{$\begin{array}{l}\text { Planned } \\
\text { Integrated }\end{array}$} & \multicolumn{2}{|c|}{ Grammar } & \multicolumn{2}{|c|}{ Secondary } & Others & \multicolumn{2}{|c|}{$\underline{\text { Total }}$} & \multirow{2}{*}{$X^{2}$} & \multirow{2}{*}{$\mathrm{df}$} & $\mathrm{P}$ \\
\hline & $\mathrm{N}$ & $\%$ & $\mathrm{~N}$ & $\%$ & $\mathrm{n}$ & $\%$ & N \% & $\mathrm{N}$ & $\%$ & & & \\
\hline Yes & 92 & 9.7 & 519 & 54.7 & 320 & 33.8 & 17 & 948 & 100 & 4.828 & 3 & \\
\hline
\end{tabular}




\begin{tabular}{|c|c|c|c|c|c|c|c|c|c|c|c|c|c|}
\hline & \multicolumn{2}{|c|}{$\begin{array}{l}\text { Planned } \\
\text { Integrated }\end{array}$} & \multicolumn{2}{|c|}{ Grammar } & \multicolumn{2}{|c|}{ Secondary } & \multicolumn{2}{|c|}{ Others } & \multicolumn{2}{|c|}{$\underline{\text { Total }}$} & \multirow[t]{3}{*}{$X^{2}$} & \multirow[t]{3}{*}{$\mathrm{df}$} & \multirow[t]{2}{*}{$\mathrm{P}$} \\
\hline & $\mathrm{N}$ & $\%$ & $\mathrm{~N}$ & $\%$ & $\mathrm{n}$ & $\%$ & $\mathrm{~N}$ & $\%$ & $\mathrm{~N}$ & $\%$ & & & \\
\hline No & 13 & 7.7 & 87 & 51.8 & 61 & 36.3 & 7 & & 168 & 100 & & & \\
\hline Total & 105 & 9.4 & 609 & 54.3 & 381 & 34.1 & 24 & & 1116 & 100 & & & \\
\hline
\end{tabular}

*Statistically not significant at p>.05

Finally, a similar finding is also demonstrated by religion and the 16year old young people's attitudes toward learning a foreign language. The analysis indicated that no statistically significant relations between the 16year old adolescents with religion backgrounds and those with no religion backgrounds as indicated by $\left(X^{2}=1.495, \mathrm{df}=1, \mathrm{p}>0.05\right)$. In other words, the null-hypothesis as proposed in this study is accepted and the alternative hypothesis (there are no significant differences between young people's attitudes to the foreign language learning in relation to the religion) is rejected.

Table 5. Proportion of Religion and Attitudes toward Foreign Language Learning

\begin{tabular}{|c|c|c|c|c|c|c|c|c|c|}
\hline & \multicolumn{2}{|c|}{ Religion } & \multicolumn{2}{|c|}{ No Religion } & \multicolumn{2}{|c|}{ Total } & \multirow{2}{*}{$X^{2}$} & \multirow{2}{*}{$\mathrm{df}$} & \multirow{2}{*}{$\mathrm{P}$} \\
\hline & $\mathrm{N}$ & $\%$ & $\mathrm{~N}$ & $\%$ & $\mathrm{~N}$ & $\%$ & & & \\
\hline Yes & 674 & 69.7 & 293 & 30.3 & 967 & 100 & 1.495 & 1 & $.221^{*}$ \\
\hline No & 130 & 74.3 & 45 & 25.7 & 175 & 100 & & & \\
\hline Total & 804 & 70.4 & 338 & 29.6 & 1142 & 100 & & & \\
\hline
\end{tabular}

*Statistically not significant at $\mathrm{p}>.05$

Section 2 discusses the results of the analyses concerning the relationship of the five examined variables (gender, residential location, school type attended, family affluence and religion) with the adolescents' attitudes toward learning a foreign language.

\section{DISCUSSION}

The statistical analysis using Chi-square on relations between the 16-year old adolescents' attitudes toward learning a foreign language with those five different variables (gender, residential location, family affluence, school type attended and religion) presented above revealed that two variables e.g., gender and residential location demonstrated statistically significant relations to the 16-year old adolescents' attitudes toward learning a foreign language. Conversely, other three variables (family affluence, school type attended and religion) are found not to show significant relations statistically to the adolescents' attitudes toward learning a foreign language. The statistically significant relation between gender and the 16-year old adolescents' attitudes towards learning a foreign language as found in this study correlates with previous studies reporting that gender is one of many factors that has relation with one's attitudes towards learning a foreign language (e.g., Kobayashi, 2002; Clark \&Trafford, 1995; Ellis, 1994; Bacon \& 
Finnemann, 1992; Powell \& Batters, 1985). Previous studies focusing on examining the relationship between the two variables reported that girls gained better performance in their learning of foreign language than boys (Titus et al., 2016; Główka, 2014; Rua, 2006; Kobayashi, 2002; Clark \& Trafford, 1995) because girls had more positive attitudes and did more efforts to master the new language than boys (Michonska-Stadnik, 2004). This can be seen in Figure 4.2.1 below in which female attitudes toward a foreign language learning is higher (61.6\%) than male (38.4\%). On the other hand, Bacon (1992) and Boyle (1987) reported no significant relation statistically between gender and attitudes toward learning a foreign language. For example, Bacon (1992) reported that there were no statistically significant gender differences in Spanish listening tasks of the 1000 participants of her research. This finding suggests that other factors may play a role in relation to attitudes of the adolescents in learning a foreign language (Lopez, 2006).

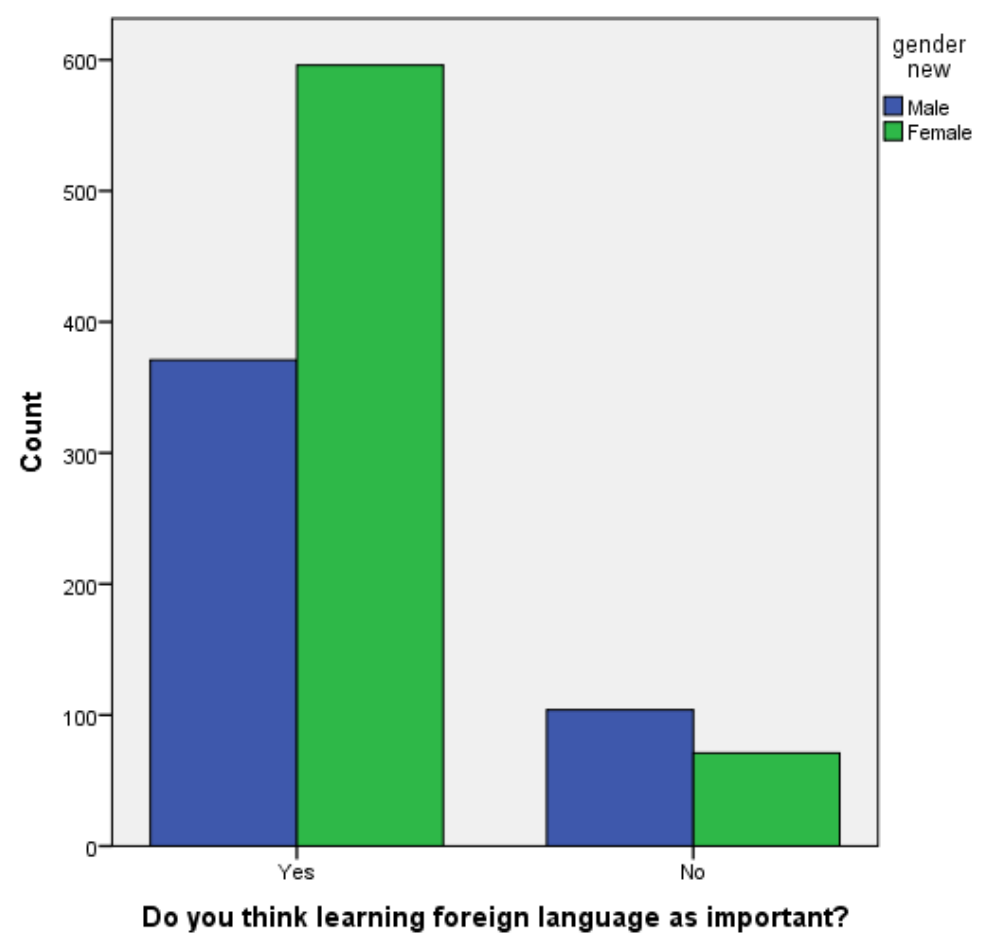

Figure 1. Proportions of Gender to Foreign Language Attitudes

In addition to gender, residential location shows a similar relation as gender towards the 16-year old adolescents' attitudes of learning a foreign language as can be seen in Figure 2 where adolescents from urban areas tended to have higher proportions with $87.54 \%$ in terms of their attitudes toward learning a foreign language than those young men from rural areas $(81 \%)$. This is in line with studies previously conducted by other researchers 


\section{Udi Samanhudi}

which reported that residential location is relating with one's attitudes toward learning a foreign language (Oey_Gardiner, 2000). For example, due to a high competition among community members and sufficient supporting facilities for their learning, those living in urban areas tended to perform better in terms of foreign language learning than those living in rural areas. This competitive situation has encouraged the 16-year old adolescents living in urban areas to have positive attitudes to learning a foreign language (Alordiah, Akpadaka, \& Oviogbodu, 2015; Oey-Gardiner, 2000) in order to support them to succeed in their learning the foreign language (OpokuAsare \& Siaw, 2016).

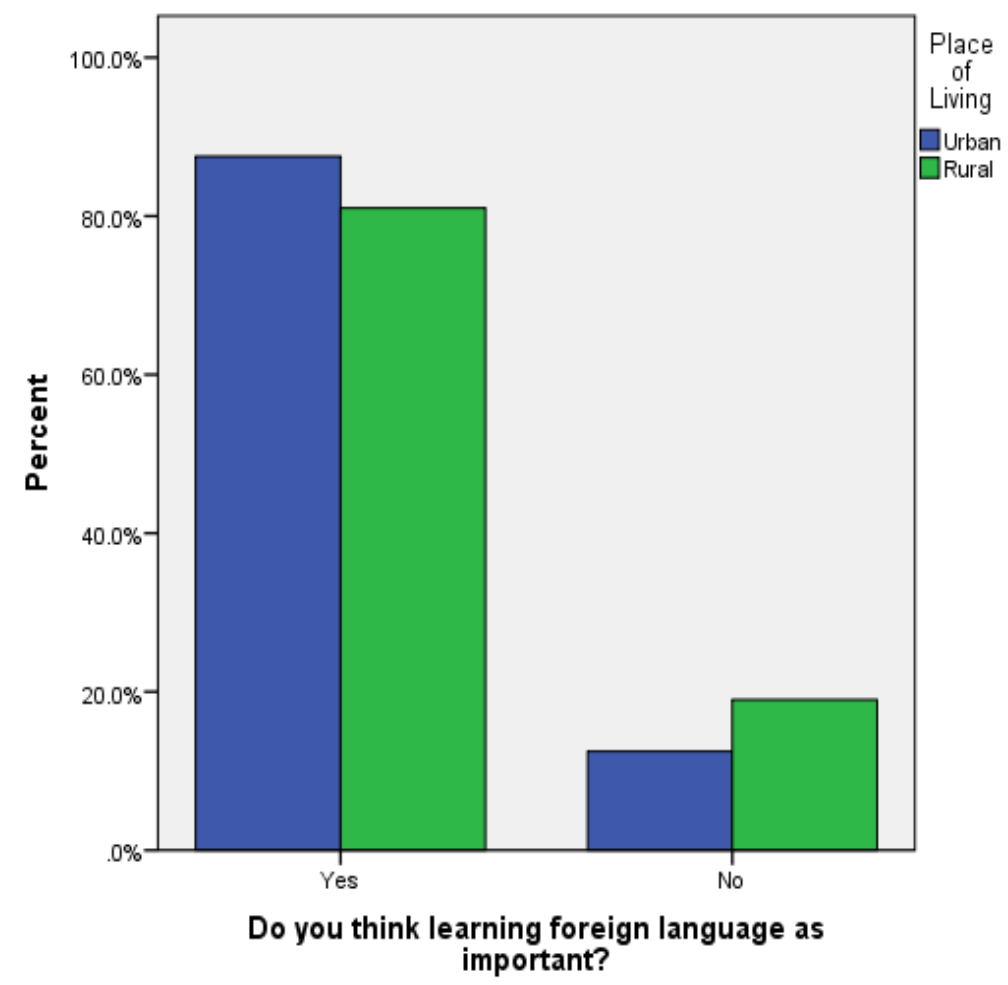

Figure 2. Proportions of Residential Locations to Foreign Language Attitudes

However, the results of the statistical analysis as presented above shows no significant relation among other three variables analysed in this study i.e., family affluence, school type attended and religion. Although recent studies indicate significant statistical relations between religion (Liyanage, et al., 2003), school type attended (Deem 1984; Spender \& Sarah 1980), family affluence (Khansir et al., 2016; Alordiah, Akpadaka \& Oviogbodu, 2015; Anderson et.al. 2007; Oey-Gardiner, 2000) with adolescents' attitudes towards learning a foreign language, this study shows that no relation is found between these three variables with the attitudes of learning a foreign language. This shows that there was no sufficient 
statistical evidence that the differences in terms of religions, school types attended and economic backgrounds at home encouraged to the differences in the adolescents' attitudes to the learning of a foreign language. In the case of religion context for example as presented in Figure 3 below, it is clear that there is no significant statistical relation between adolescents belong to any particular religion in terms of their attitudes to learn a foreign language $(69.7 \%)$ and those with no religion background (30.3\%).

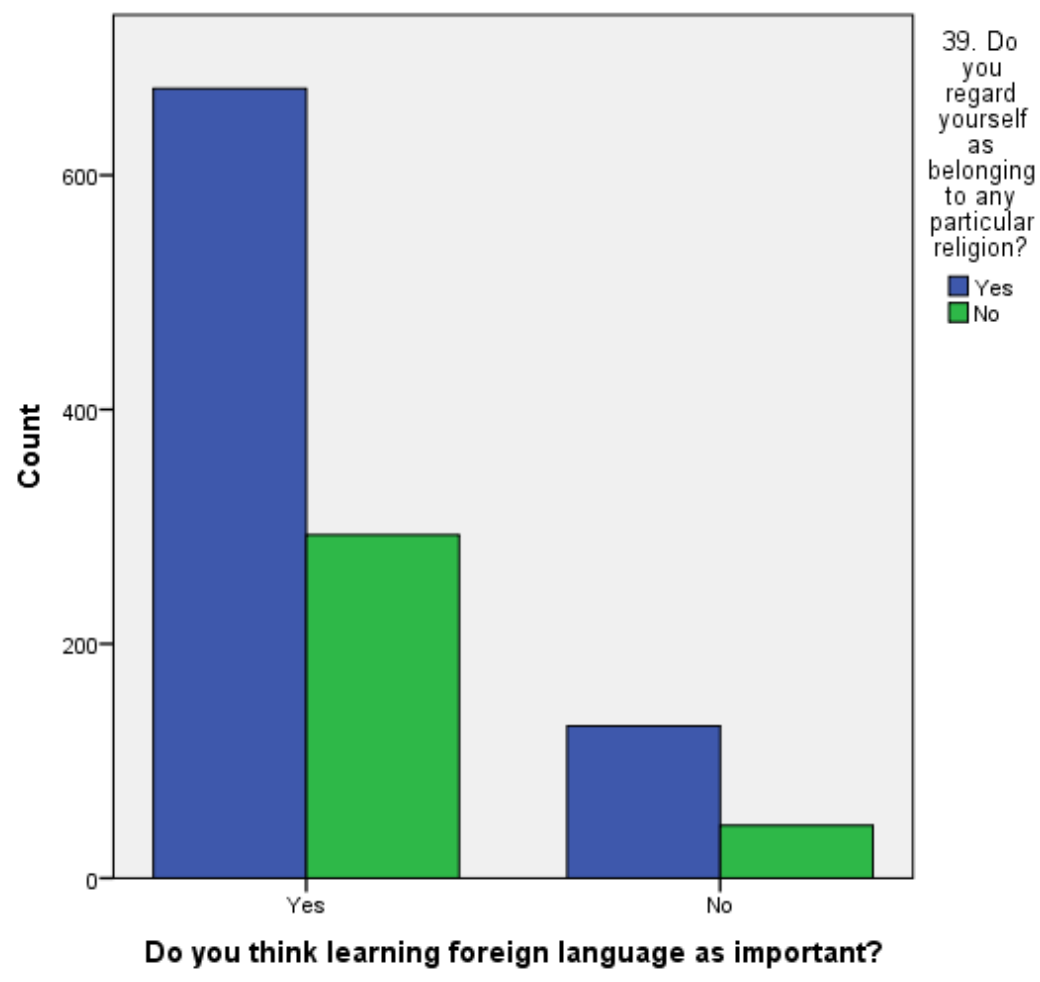

Figure 3. Proportions of Religion to Foreign Language Attitudes

In the case of school type attended, it is important to note that the finding which reports no statistical relation between types of school attended and attitudes toward a foreign language learning is in line with Daly's finding in Northern Ireland context. It is reported that no significant difference of achievement in terms of learning a foreign language between single-sex and mixed grammar schools. Similar results are also reported that no significant differences found in other subjects including Math and English (Daly \& Shuttleworth, 1997; Daly 1995, 1996). Finally, in terms of family affluence, the absence of statistical relation with the adolescents' attitude toward learning a foreign language might be caused by the fact that English is an international language that places its prestigious language so that learning a foreign language might not be considered important by the adolescents in UK in general and in Northern Ireland in particular (DfES, 
2002). This is in contrast with the adolescents in other contexts who are keen of learning a foreign language especially English due to benefits it offers for their future education and career. Khansir et al., (2016), for example, reported a study of 230 Iranian studying in the third grade of high school who had positive attitudes towards learning a foreign language especially English. They reported that there is a significant relation between parents' socio-economic status with students' attitudes toward learning a foreign language in that parents from high socio-economic status tend to support and facilitate their children to learn a foreign language. The fact that no significant relation between the three variables (religion, types of school attended and family affluence) with the attitudes of learning a foreign language also correlates with Lopez's (2006) statement, as mentioned above, that there are many other factors relating to one's attitudes toward a foreign language learning such as they themselves as learners and the environment surrounding them.

\section{CONCLUSION AND LIMITATIONS}

This study has found that gender and residential locations were significant factors relating to the 16-year old adolescents' attitudes toward learning a foreign language. Conversely, this study found that there was no statistically significant evidence of differences among the other three variables (the family affluence, school types attended and religions) in relation to the young people's attitudes to the foreign language. In terms of limitation, this study is based on five questions related to gender, residential location, family affluence, types of schools attended and religion of 16 year old adolescents who responded to the 2015 YLT survey. These results, therefore, cannot be made as a main reference for a policy change in the future especially one that is related to current modern language learning policy i.e., Languages for All: Languages for Life. However, this study provides focused insight into the 16 year old teenagers' current attitudes towards foreign language learning based on the five different characteristics examined. This may be useful as a reflection of how the current modern language learning policy is implemented and how teenagers especially in the context of Northern Ireland respond to the policy.

\section{BIOGRAPHY}

Udi Samanhudi is a faculty member at the English Education Department of Sultan Ageng Tirtayasa State University Banten, Indonesia and is now a doctoral student in TESOL at Queen's university of Belfast, the United Kingdom (UK). He completed his bachelor degree in the area of English Education in Yogyakarta State University and master program at the same area in Indonesia University of Education, Bandung. His research interest 
Northern Irish adolescents' attitudes towards learning a foreign language...

includes discourse analysis, genre analysis in language education, critical writing pedagogy and teaching English in EFL context. His current articles were published in Compare: A Journal of Comparative and International Education, The Asian EFL Journal and Indonesian Research Journal in Education (IRJE) and International Journal of Language Teaching and Education.

\section{REFERENCES}

Ali, N. L., Hamid, M. O., and Moni, K. (2011) 'English in primary education in Malaysia: policies, outcomes and stakeholders' lived experiences', Current Issues in Language Planning, 12(2), pp147-166.

Aldashev, A., Gernandt, J. \& Thomsen, S. (2009) 'Language usage, participation, employment and earnings: Evidence for foreigners in West Germany with multiple sources of selection', Labour Economics, 16, pp330-341.

Alordiah, C., Akpadaka, G. and Oviogbodu, C. (2015) 'The influence of gender, school location and socio-economic status on students' academic achievement in mathematics', Journal of Education and Practice, 6(17), pp130-136.

Anderson, J., Lin, H., Tragust, D., Ross, S. and Yore, L. (2007) 'Using largescale assessment datasets for research in science and mathematics education: Programme for international student assessment (PISA)', International Journal of Science and Mathematics Education, 5, pp591-614.

Bacon, S.M., (1992) 'The relationship between gender, comprehension, processing strategies, and cognitive and affective response in foreign language listening'. The modern language Journal, 76(2), pp.160-178.

British Council \& Think Global (2015) The global skills gap - preparing young people for the new global economy. Retrieved on January 10, 2017 from https://think-global.org.uk/wpcontent/uploads/dea/documents/BusinessPoll_online_TG.pdf

British Council (2011) Broadening horizons: The value of the overseas experience. Retrieved on January 10, 2017 from www.britishcouncil.org/sites/default/files/6.3_broadeninghorizons-2015.pdf

Boninger, D.S., Krosnick, J.A., Berent, M.K. and Fabrigar, L.R., (1995) 'The causes and consequences of attitude importance'. Attitude strength: Antecedents and consequences, 4, pp.159-189.

Bryman, A. (2012, 4th Edition) Social research methods. Oxford: Oxford University Press.

Boyle, J.P., (1987) 'Sex differences in listening vocabulary'. Language learning, 37(2), pp.273-284.

Cable, C., Driscoll, P., Mitchell, R., Sing, S., Cremin, T., Earl, J., Eyres, I., 
Holmes, B., Martin, C. \& Heins, B. (2012). 'Language learning at Key Stage 2: findings from a longitudinal study', Education 3-13, 40(4), pp363-378.

Chambell, J. (2016) Household wealth: Study suggests NI is 'most economically equal part of UK'. Retrieved on January 20, 2017 from http://www.bbc.co.uk/news/uk-northern-ireland-36208779

Chiswick, B. \& Miller, P. (2003) 'The complementarity of language and other human capital: immigrant earnings in Canada', Economics of Education Review, 22, pp469-480.

Clark, A., \&Trafford.(1995) `Boys into Modern Languages: an Investigation in Attitudes and Performance Between Boys and Girls in Modern Languages'. Gender and Education, 7, pp.315-325.

Cohen, L., Manion, L. and Morrison, K., 2011. Planning educational research. Research methods in education. New York: Routledge Editors.

Cohen, A. D. (2014). Strategies in learning and using a second language. Routledge.

Cohen, L., Manion, L., \& Morrison, K. (2011, 7th Edition) Research Method in Education. Oxon: Routledge.

Conolly, P. (2007) Quantitative data analysis - A critical Introduction using SPSS. London: Sage.

Daly, P., (1996) 'The effects of single-sex and coeducational secondary schooling on girls' achievement'. Research Papers in Education, 11(3), pp.289-306.

Daly, P., (1995) 'Science course participation and science achievement in single sex and co-educational schools'. Evaluation $\mathcal{E}$ Research in Education, 9(2), pp.91-98.

Daly, P. and Shuttleworth, I., (1997) ‘Determinants of public examination entry and attainment in mathematics: Evidence on gender and gender-type of school from the 1980s and 1990s in Northern Ireland'. Evaluation E Research in Education, 11(2), pp.91-101.

Dörnyei, Z., (1994) 'Motivation and motivating in the foreign language classroom'. The modern language journal, 78(3), pp.273-284.

Ellis, R., 2015. Understanding Second Language Acquisition 2nd Edition-Oxford Applied Linguistics. Oxford university press.

Ellis, R., 1994. The study of second language acquisition. Oxford University.

Fan, W. (2011) 'Social influences, school motivation and gender differences: An application of the expectancy-value theory'. Educational Psychology Review, 31(2), pp157-175.

Gardner, R.C. and Lambert, W.E., (1972). Attitudes and Motivation in Second-Language Learning. Rowley, MA: Newbury House

Główka, D. (2014). 'The impact of gender on attainment in learning English as a foreign language'. Studies in Second Language Learning and 
Northern Irish adolescents' attitudes towards learning a foreign language...

Teaching, 4(4), pp617-635.

Karahan, F. (2007) 'Language attitudes of Turkish students towards the English language and its use in Turkish context. Journal of arts and sciences, 7(1), pp73-87.

Khansir, A. A., Jafarizadegan, N., \& Karampoor, F. (2016) ‘Relation between socio-economic status and motivation of learners in learning English as a foreign language. Theory and Practice in Language Studies, 6(4), pp742.

Hayes, B. C., McAllister, I., \& Dowds, L. (2013). 'Integrated schooling and religious tolerance in Northern Ireland'. Journal of Contemporary Religion, 28(1), pp67-78.

Hedge, T. (2001). Teaching and learning in the language classroom (Vol. 106). Oxford,, UK: Oxford University Press.

Hernández, T. A. (2010) 'The relationship among motivation, interaction, and the development of second language oral proficiency in a studyabroad context'. The Modern Language Journal, 94(4), pp600-617.

Hosseini Fatemi, A., \& Khaghaninezhad, M. S. (2012) 'The Role of Ethnicity in Integrative Tests Performances of Male/Female Iranian English Learners of Different Language Proficiency Levels'. Journal of Teaching Language Skills, 30(2), pp29-56.

Hughes, J., Campbell, A., \& Jenkins, R. (2011) ‘Contact, trust and social capital in Northern Ireland: a qualitative study of three mixed communities'. Ethnic and Racial Studies, 34(6), pp967-985.

Hurtado, A., \& Gurin, P. (1987) 'Ethnic identity and bilingualism attitudes'. Hispanic Journal of Behavioral Sciences, 9(1), pp1-18.

Khansir, A. A., Jafarizadegan, N., \& Karampoor, F. (2016) 'Relation between socio-economic status and motivation of learners in learning English as a foreign language'. Theory and Practice in Language Studies, 6(4), pp742.

Kobayashi, Y. (2002). 'The role of gender in foreign language learning attitudes: Japanese female students' attitudes towards English learning'. Gender and education, 14(2), pp181-197.

Kormos, J., \& Kiddle, T. (2013) 'The role of socio-economic factors in motivation to learn English as a foreign language: The case of Chile'. System, 41(2), 399-412.

Labov, W., 1990. 'The intersection of sex and social class in the course of linguistic change'. Language variation and change, 2(02), pp.205-254.

López Rúa, P. (2006). 'The sex variable in foreign language learning: an integrative approach'. Porta Linguarum 6(6), pp99-114.

Liyanage, I., Birch, G., \& Grimbeek, P. (2004) 'Religion, Ethnicity and Language Learning Strategies'. Proceedings of the $2^{\text {nd }}$ Annual International Conference on cognition, language and special education, 3-5 
December, 2004. pp. 222-229

Masgoret, A. M., \& Gardner, R. C. (2003) 'Attitudes, motivation, and second language learning: a meta-analysis of studies conducted by Gardner and associates'. Language learning, 53(1), pp123-163.

Mburu, D.N., (2013) 'Effects of the type of school attended on students academic performance in kericho and kipkelion districts, kenya'. International Journal of Humanities and Social Science 3 (4), pp. 79-90

McGroarty, M., (1996) ' Language attitudes, motivation, and standards'. Sociolinguistics and language teaching, pp.3-46.

Michońska-Stadnik, A., (2004) 'Gender differences and preferred learning environment in a foreign language classroom'. Pragmatics and language learning, 3(5) pp.183-192.

Muñoz, C., (2008) 'Symmetries and asymmetries of age effects in naturalistic and instructed L2 learning'. Applied Linguistics, 29(4), pp.578-596.

Murphy, B., (2010) 'Foreign language learning in Irish second level schools: gender very much on the agenda'. Irish Educational Studies, 29(1), pp.81-95.

Nikolov, M. (2009). Early modern foreign language programmes and outcomes: Factors contributing to Hungarian learners' proficiency. In M. Nikolov (Ed.), Early learning of modern foreign languages (pp. 90107). Bristol: Multilingual Matters.

Norton, B., (2000) Identity and language learning: Gender, ethnicity and educational change. Editorial Dunken.

Oxford, R. and Shearin, J., (1994)' Language learning motivation: Expanding the theoretical framework'. The modern language journal, 78(1), pp.1228.

Oey-Gardiner, M. (2000) 'Schooling in a decentralized Indonesia: New approaches to access and decision making', Bulletin of Indonesian Economic Studies, 36(3), pp127-134.

Opoku-Asare, N. and Siaw, A. (2016) 'Curricula and inferential factors that affect student achievement in rural, urban, and peri-urban senior high schools in Ghana: Evidence from the visual arts program', SAGE Open, pp1-13. Retrieved on January 12, 2017 from https:// us.sagepub.com/en-us/nam/open-access-at-sage.

Perry, C. and Love, B. (2013) 'Rural schools', Research and Information Service Research Paper/ Northern Ireland Assembly, Retrieved on January 20, 2017 from http://www.niassembly.gov.uk/globalassets/documents/raise/pub lications/2013/education/2713.pdf.

Punch, K. (2005, 2 ${ }^{\text {nd }}$ Edition) Introduction to social research - quantitative and qualitative approaches. London: Sage Publications

Rao, J. and Ye, J. (2016) 'From a virtuous cycle of rural-urban education to 
urban-oriented rural basic education in China: An explanation of the failure of China's rural school mapping adjustment policy', Journal of Rural studies, 47, pp601-611.

Roberts, L. and Allen, P. (2015) 'Exploring ethical issues associated with using online surveys in educational research', Educational Research and Evaluation, 21(2), pp95-108.

Pavlenko, A. and Piller, I., (2008) ‘Language education and gender. In Encyclopedia of language and education (pp. 57-69). Springer US.

López Rúa, P., (2006) ' The sex variable in foreign language learning: an integrative approach'. PORTA LINGUARUM 6(3), pp. 99-114.

Schubotz, D. \& McCartan, C. (2016) 'Attitudes to language learning and internationalization - Evidence from 2015 Young Life and Times (YLT)', Northern Ireland Young Life and Time, pp1-34.

Shuttleworth, I., and Lloyd, C. (2001) Mapping segregation in Northern Ireland. Belfast: House Executive.

Shaaban, K., \& Ghaith, G. (2003). Effect of religion, first foreign language, and gender on the perception of the utility of language. Journal of language, identity, and education, 2(1), 53-77. 